\title{
Vermicomposting of Sewage Sludge: Earthworm Population and Agronomic Advantages
}

\author{
Solis-Mejia Ludibeth, Islas-Espinoza Marina and Esteller Ma. Vicenta \\ Centro Interamericano de Recursos del Agua, Facultad de Ingeniería, \\ Universidad Autónoma del Estado de México, México \\ *E-mail contact: ludisolis@hotmail.com
}

\begin{abstract}
Optimal substrates for vermicompost should ensure survival and reproduction of earthworms, as well as vermicompost quality. This concerns especially waste material substrates. Therefore, the objectives of this study were to estimate the adaptation of Eisenia foetida to mixtures of sewage sludge and composted cow dung, and also to evaluate the quality of the vermicompost as fertilizer. Four treatments contained sewage sludge and composted cow dung in ratios of 70:30 (A), 80:20 (B), 90:10 (C) and 95:5 (D), with 60-70\% moisture. The samples were incubated at $17 \pm 2{ }^{\circ} \mathrm{C}$ with 50 adult earthworms each. Following 50 days of composting, cocoons, juveniles and adult earthworms were counted and several physicochemical parameters were determined. E. foetida could not survive treatment D. Treatments A and B had the highest survival and reproduction. However, treatment $\mathrm{C}$ showed the highest amounts of available N and P (2189.80 and $2310.63 \mathrm{mg} \mathrm{kg}^{-1}$, respectively) and a C:N ratio of 12.46 , making it a better fertilizer. The values of bulk density $\left(0.64 \mathrm{~g} \mathrm{~cm}^{-3}\right)$, organic matter $(54.82 \%)$, organic $\mathrm{C}(31.80 \%)$, available $\mathrm{K}\left(1801.92 \mathrm{mg} \mathrm{kg}^{-1}\right)$ and total $\mathrm{N}$ $(2.55 \%)$ for treatment $\mathrm{C}$ were within the ranges for vermicompost recommended in the Mexican guidelines. Significant differences were found in all physical and chemical parameters $(\mathrm{p}<0.05)$, except for $\mathrm{P}$. Fractionation of $\mathrm{P}$ in treatment $\mathrm{C}$ and sewage sludge showed that the largest proportion of $\mathrm{P}$ is slightly soluble in water and so, available to plants. Overall, this study suggests that sewage sludge and cow dung vermicomposted with $E$. foetida can improve fertility and nutrient availability, as well as earthworm population growth, compared with the sewage sludge alone.
\end{abstract}

\section{Introduction}

Wastewater treatment plants in Mexico generated in the last decade an estimated 493,000 to $1,500,000 \mathrm{Mg}$ $\mathrm{yr}^{-1}$ of sewage sludge due to biological processes that digest organic matter from households (Garrido et al. 2005a). Current disposal of sewage sludge using sludge reactors or dehydration systems is costly (CardosoVigueros and Ramírez-Camperos 2002), while on the other hand, sewage sludge has been used on agricultural land for a long time to add macro and micro nutrients and organic matter to the soil (Rostagno and Sosebee 2001; Hernández-Herrera et al. 2005). Environmental problems, e.g. the egression of human pathogens to water, soil and air, are also associated with the management of sewage sludge (FrancoHernández et al. 2003; Penn and Sims 2002; Shober and Sims 2003; Esteller et al. 2009). These issues could be significantly reduced by stabilizing sludge before its disposal or agricultural use (Epstein 2003). Composting and vermicomposting are two of the best-known processes for the biological stabilization of different natural and anthropogenic solid organic wastes, in- cluding sewage sludge (Short et al. 1999; Kaushik and Garg 2003; Capistrán et al. 2004; Vaca et al. 2005; Díaz et al. 2007; Frederickson et al. 2007). Vermicomposting involves among other processes, the biooxidation, digestion, and mineralization of organic material; in contrast to composting, it depends on the joint action of earthworms, and microorganisms; finally it does not need nor indeed must involve a thermophilic stage (Capistrán et al. 2004; Díaz et al. 2007). During vermicomposting, the important nutrients such as nitrogen, phosphorus, potassium, and calcium present in the feed material are converted through microbial action into forms that are much more soluble and available to plants than those in the parent substrate (Kaushik and Garg 2003). Microorganisms produce the enzymes that cause the biochemical decomposition of organic matter, but earthworms are crucial drivers of the process as they aerate and fragment the substrate, and mobilize the nutrients, thereby drastically altering the microbial activity (Trigo et al. 1999). Earthworms mechanically comminute and blend the organic matter, increase the surface area exposed to microorganisms who in turn reduce the C:N ratio - making microbial decomposition 
easier (Albanell et al. 1988; Garg et al. 2006; Liu et al. 2005). All materials digested by the earthworms' intestines show enhanced agricultural properties (fine texture, more easily attacked by bacteria, fungi and actinomycetes) and are enriched with substances commonly called growth regulators (Díaz et al. 2007). Earthworms also modify microbial biomass and activity through stimulation, digestion and dispersion in casts, thereby affecting the structure and function of microbial communities (Feller et al. 2003; Barois et al. 1999). The application of soil amendment products digested by earthworms enriches microbial metabolites which, in turn, stimulate vegetal crop yield (Díaz et al. 2007).

Recent studies have used different proportions of sludge as substrate for vermicomposting: 0-70\% mixed with cow dung (Kaushik and Garg 2003); 49-70\% with water hyacinth (Cardoso-Vigueros and RamírezCamperos 2002); and 50-85\% with cow dung (Contreras-Ramos et al. 2005). Other experiments have used composted and fermented sewage sludge to feed Eisenia foetida (Kaushik and Garg 2003; Liu et al. 2005; Garg et al. 2006). However, the problems in this set of reports seem to be: a relatively wide uncertainty as regards the optimal mixtures (what to mix and in which proportions). And also, composting and fermentation imply time as well as economic costs associated to periodical homogenization of pile or vessel contents. Accordingly, this study will try to improve on previous reports by using fresh sludge (without previous composting), in higher proportions than studied up until now (70-95\%).

The objectives of this study are firstly, to estimate survival and reproduction of E. foetida in different mixtures of sewage sludge with cow dung. And secondly, to evaluate the physicochemical characteristics and quality of the vermicompost as fertilizer.

\section{Materials and Methods}

\section{Collection of E. foetida, Sewage Sludge and Cow Dung}

Adult earthworms (E. foetida) were randomly collected from horse dung at the Faculty of Agricultural Science of the Mexico State Autonomous University. Fresh sewage sludge was obtained from the Toluca North wastewater treatment plant, located in Toluca, State of Mexico. Cow dung (a mixture of feces and urine composted during one year to benefit from spontaneous microbial colonization) was obtained from a farm in Lerma, State of Mexico. Composted cow dung was used, as it is more suitable than fresh manure for earthworm population growth (GutiérrezVázquez et al. 2007), and as it has more oxygen and avoids fermentation gases which bring about earthworm mortality.

\section{Experimental Design}

Four 0.8-kg mixtures of sewage sludge and cow dung (A, B, C and D) were prepared with the following dry weight ratios: 70:30, 80:20, 90:10 and 95:5\%, respectively. The use of more than $70 \%$ of fresh sewage sludge was intended to reuse the highest amount possible of sewage sludge, to reduce the problem of its disposal. The mixtures were manually homogenized and placed in plastic bottles $(3 \mathrm{~L}, 12 \mathrm{~cm}$ diameter, 25 $\mathrm{cm}$ depth) perforated in the base to release leachate. Each treatment was replicated thrice. In these mixtures, 50 adult Eisenia foetida earthworms were incubated (Contreras-Ramos et al. 2005; Garg et al. 2006). Moisture was maintained at $60-70 \%$ by weight during 50 days (Contreras-Ramos et al. 2005). All the containers were kept in the dark at $17 \pm 2{ }^{\circ} \mathrm{C}$. Following 50 days of vermicomposting (Liu et al. 2005), the total number of adult and juvenile earthworms and cocoons was counted and the earthworms were manually removed to carry out physicochemical analyses. Three samples of sewage sludge were air dried and sieved to be included as controls. The unmixed cow dung samples were also analyzed.

\section{Chemical Analyses}

At the end of 50 days of vermicomposting, three samples of each vermicomposted mixture were air dried in the shade at room temperature, ground and sieved ( $2 \mathrm{~mm}$ diameter) according to the Mexican vermicomposting standard (NMX-FF-109-SCFI-2007). Bulk density, electrical conductivity (Porta et al. 2003), and $\mathrm{pH}$ (Jackson 1982) were determined. Organic matter was estimated by ignition at $550^{\circ} \mathrm{C}$ and total organic carbon was obtained assuming that organic carbon corresponds to $58 \%$ of total organic matter (Primo and Carrasco 1981). Total Kjeldahl nitrogen was determined (Cardoso-Vigueros and Ramírez-Camperos 2002). Available phosphorus and nitrogen were estimated as suggested by Olsen and Summers (1982) and by extracted $\mathrm{KCl}$, respectively (Siddique and Robinson 2004; Mariani et al. 2007). P fractionation was carried out according to Penn and Sims (2002). Available $\mathrm{K}$ and $\mathrm{Na}$ were determined using atomic emission spectroscopy (Liu et al. 2005).

\section{Statistical Analyses}

One-way analysis of variance (ANOVA) was used to test treatment effects (Contreras-Ramos et al. 2005). Differences between treatment means were calculated using the Tukey test, at a 0.05 level of significance. Statistical analyses were performed using SAS v. 5.0. 


\section{Results and Discussion}

In terms of earthworm population dynamics, using high proportions of sewage sludge $(\geq 95 \%)$ provoked the death of E. foetida, possibly due to oxygen deficiency (Kaushik and Garg 2003) and toxicity following ammonification in fresh sewage sludge (Carbonell et al. 2009). At the end of the vermicomposting process, treatment $A$ showed 55 adults earthworms, treatment B maintained the initial number (50 adults), and treatment $C$ showed a decrease to 40 units (Table 1); however, this trend of lower adult survival related to higher sewage sludge proportions in the substrate was not statistically significant. As to juvenile earthworms, averages of 18 were found in treatments $A$ and $B$ as against 4 in treatment $C$. Treatments $A$ and $B$ also showed higher numbers of cocoons. The foregoing suggests that the proportion of sludge in the mixtures influenced mainly the reproduction of the earthworms.

As regards physical characteristics, the bulk densities were $0.80,0.65$ and $0.64 \mathrm{~g} \mathrm{~cm}^{-3}$ (treatments A, B and $\mathrm{C}$, respectively). These values are within the 0.40 $0.90 \mathrm{~g} \mathrm{~cm}^{-3}$ range (Table 2) which is appropriate for vermicompost in the Mexican standards (NMX-FF109-SCFI-2007). Bulk density is most relevant to plant health, as an indicator of soil porosity and its resistance to root growth. Electrical conductivity in sewage sludge was $2.64 \mathrm{dS} \mathrm{m}^{-1}$, slightly higher than $2.20 \mathrm{dS} \mathrm{m}^{-}$ ${ }^{1}$ in cow dung (Table 2). Vermicompost conductivity

TABLE 1.

Treatments, survival and reproduction of E. foetida ( $\mathrm{n}=3$, average \pm standard deviation)

\begin{tabular}{lccccc}
\hline \multirow{2}{*}{ Treatment } & $\begin{array}{c}\text { Sewage Sludge } \\
(\%)\end{array}$ & $\begin{array}{c}\text { Cow Dung } \\
(\%)\end{array}$ & Adults & \begin{tabular}{c} 
Juveniles \\
\cline { 5 - 6 } (units)
\end{tabular} & Cocoons \\
\hline A & 70 & 30 & $55 \pm 21$ & $19 \pm 5$ & $136 \pm 50$ \\
B & 80 & 20 & $50 \pm 34$ & $18 \pm 7$ & $151 \pm 17$ \\
C & 90 & 10 & $40 \pm 33$ & $4 \pm 1$ & $55 \pm 19$ \\
D & 95 & 5 & 0 & 0 & 0 \\
\hline
\end{tabular}

Note: The initial population was 50 adult earthworms per treatment. was $4.16 \mathrm{dS} \mathrm{m}^{-1}$ for treatment A and $3.28 \mathrm{dS} \mathrm{m}^{-1}$ for B and C, similar to Carbonell et al. (2009). These values were generally below $4 \mathrm{dS} \mathrm{m}^{-1}$, a threshold value for moderate but significantly higher mortality and lesser earthworm population growth, attributable to acid $\mathrm{pH}$ and higher amounts of salts dissolved in water (Dayananda et al. 2008). Electrical conductivity is dependent on freely available minerals and ions, generated during ingestion and excretion by the earthworms (Garg et al. 2006). The electrical conductivity in the sewage sludge, cow dung and vermicomposts were classified as low in salts according to the Mexican standard for soils (NOM 021-SEMARNAT-2000).

Regarding chemical characteristics, the sewage sludge had an acid $\mathrm{pH}(6.02)$ at the beginning of the experiment (Table 2) which was further lowered after 50 days of vermicomposting (5.65-5.82). Treatment A was significantly different from B and C (Table 2). Acid $\mathrm{pH}$ probably owed to $\mathrm{CO}_{2}$ and organic acids produced during mixture decomposition by microbial metabolism, as well as to the presence of $\mathrm{NO}_{3}$ and $\mathrm{NO}_{2}^{-}$ions, which are weak bases causing ionic acidity (Garg et al. 2006). It is worth mentioning that $\mathrm{pH}$ has a decisive influence on the availability of nutrients to plants, and the efficiency with which plants can absorb nutrients (Adams 1995).

Organic matter content in sewage sludge was $47.31 \%$ and highest in cow dung $(70.02 \%)$, followed by treatment A (60.70\%). So it appears that cow dung additions controlled organic matter in the treatments (Table 2). It has been shown that a high percentage of organic matter favors growth of earthworms. When the earthworm population is high, the process of decomposition of organic matter is accelerated and the humification is carried out in a short time due to the action of microorganisms contained in the excreta of earthworms (Martínez, 1997). This utilization of organic matter may explain the lower organic matter content in vermicompost (treatment $\mathrm{C}$ ) compared to sewage or cow dung (Table 2). Sewage sludge organic matter was lower than previously reported elsewhere

TABLE 2.

Physicochemical characteristics of the sewage sludge, cow dung, vermicompost and Mexican official guidelines

\begin{tabular}{lcccccc}
\hline Parameter & Sewage Sludge & Cow Dung & Treatment A & Treatment B & Treatment C & Official Guidelines \\
\hline Bulk density $\left(\mathrm{g} \mathrm{cm}^{-3)}\right.$ & N.D. & N.D. & $0.80 \pm 0.06 \mathrm{a}$ & $0.65 \pm 0.06 \mathrm{~b}$ & $0.64 \pm 0.03 \mathrm{~b}$ & $0.40-0.90$ \\
Electrical conductivity $\left(\mathrm{dS} \mathrm{m}^{-1}\right)$ & $2.64 \pm 0.03 \mathrm{c}$ & $2.20 \pm 0.00 \mathrm{~d}$ & $4.16 \pm 0.41 \mathrm{a}$ & $3.28 \pm 0.18 \mathrm{~b}$ & $3.27 \pm 0.19 \mathrm{~b}$ & $\leq 4$ \\
pH & $6.02 \pm 0.03 \mathrm{a}$ & $7.38 \pm 0.15 \mathrm{~b}$ & $5.65 \pm 0.05 \mathrm{~d}$ & $5.80 \pm 0.04 \mathrm{c}$ & $5.82 \pm 0.13 \mathrm{c}$ & $5.50-8.50$ \\
Organic matter (\%) & $47.31 \pm 0.35 \mathrm{e}$ & $70.02 \pm 0.39 \mathrm{a}$ & $60.70 \pm 0.33 \mathrm{~b}$ & $56.83 \pm 0.80 \mathrm{c}$ & $54.82 \pm 1.07 \mathrm{~d}$ & $20-50$ \\
Organic carbon (\%) & $27.44 \pm 0.20 \mathrm{e}$ & $40.70 \pm 0.18 \mathrm{a}$ & $35.21 \pm 0.19 \mathrm{~b}$ & $32.96 \pm 0.46 \mathrm{c}$ & $31.80 \pm 0.62 \mathrm{~d}$ & $11-29$ \\
Total nitrogen (\%) & $3.19 \pm 0.03 \mathrm{a}$ & $1.03 \pm 0.05 \mathrm{e}$ & $1.86 \pm 0.21 \mathrm{~d}$ & $2.18 \pm 0.14 \mathrm{c}$ & $2.55 \pm 0.06 \mathrm{~b}$ & $1-4$ \\
C:N & $8.58 \pm 0.13 \mathrm{~d}$ & $39.51 \pm 2.25 \mathrm{~d}$ & $19.18 \pm 2.69 \mathrm{a}$ & $15.17 \pm 1.17 \mathrm{~b}$ & $12.46 \pm 0.44 \mathrm{c}$ & $\leq 20$
\end{tabular}

(n=3, average \pm standard deviation). Mexican official guidelines NMX-FF-109-SCFI-2007. N.D.: Not determined. N.A.: Not available. Different letters in each row indicate significant differences at $\mathrm{p}<0.05$. 
(53.65\%, Garrido et al. 2005b; 61.97\% and 65-73\%, Hogan et al. 2001, Carbonell et al. 2009). This lower initial organic matter in sewage and its biological utilization during vermicomposting probably explain why the vermicompost showed lower organic matter than the official guidelines (Table 2).

The sewage sludge contained the largest amount of total $\mathrm{N}(3.19 \%)$, followed by treatments C $(2.55 \%)$, $\mathrm{B}$, and A (Table 2). Differences between treatments were significant. Total $\mathrm{N}$ concentrations in these vermicomposts may be related to their slightly acid $\mathrm{pH}$ and ensuing $\mathrm{N}$ retention, otherwise lost as volatile ammonia at alkaline $\mathrm{pH}$ (Garg et al. 2006). Contrary to composting, vermicomposting avoids loss of nutrients such as $\mathrm{NH}_{3}$ (Contreras-Ramos et al. 2005).

The available $\mathrm{N}$, which is directly related to crop response (Miralles del Imperial et al. 2003), is shown in Figure 1. Vermicomposts A, B and C (689.66, 1081.69 and $2189.80 \mathrm{mg} \mathrm{kg}^{-1}$, respectively) considerably improved over sewage sludge $\left(162.72 \mathrm{mg} \mathrm{kg}^{-1}\right)$. This demonstrates the nutritional value of sludge in all chemical parameters (higher than cow dung except for organic matter and available potassium). But in addition, vermicompost seemed to induce a non-linear availability of $\mathrm{N}$, as sludge content increased $5 \%$ between treatments while available $\mathrm{N}$ augmented $156.8 \%$ between A and B and 202.4\% between B and C. All treatments were significantly different; available $\mathrm{N}$ augmented 17 -fold from $0.5 \%$ of the sewage sludge to $8.57 \%$ in treatment $C$ (treatments $A$ and $B$ augmented 5 and 10 times, respectively). This non-linear pattern is attributable to a synergism between earthworms and microorganisms whereby earthworms increase organic matter decomposition and accelerate the change of organic $\mathrm{N}$ to available $\mathrm{N}$, thus improving the fertility of sewage sludge (Liu et al. 2005). Nitrogen mineralization by microflora is also quite intense in the gut of earthworms and continues for several hours in fresh casts (Mariani et al. 2007).

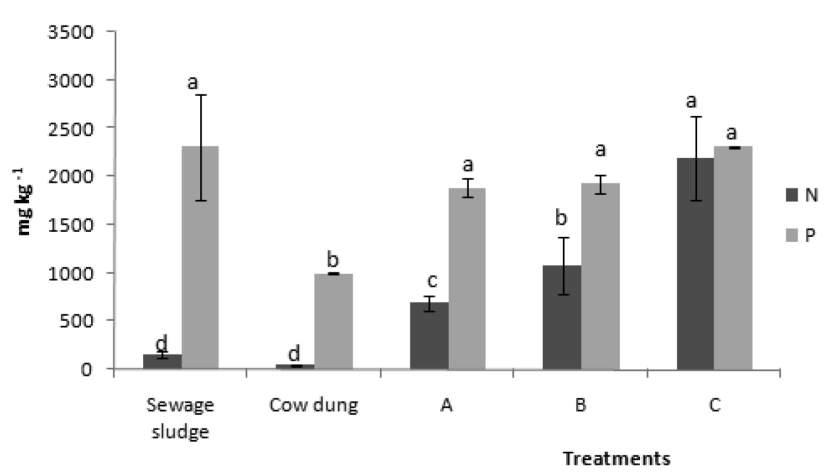

FIGURE 1. Available Nitrogen and Phosphorus. Note: Bars indicate mean \pm standard error. Different letters in each bar indicate significant differences at $\mathrm{p}<0.05$.
The average concentration of available $\mathrm{P}$ in sewage sludge was $1994.21 \mathrm{mg} \mathrm{kg}^{-1}$, similar to vermicompost (Figure 1), and much higher than cow dung. Available P is reported elsewhere at $1239 \mathrm{mg} \mathrm{kg}^{-1}$ and 369-1511 $\mathrm{mg} \mathrm{kg}^{-1}$ (Carbonell et al. 2009; Hogan et al. 2001). Several studies have found a higher content of available $\mathrm{P}$ in earthworm casts than in control samples without earthworms (Krishnamoorthy 1990; Guggenberger et al. 1996; Liu et al. 2005). Earthworms have been shown, after intestinal transit, to help desorb P from the solid phase of soil or waste; they also have a great impact on $\mathrm{P}$ mineralization as a result of faecal and bacterial phosphatase activity. Despite this acknowledged role in $\mathrm{P}$ mineralization, no increase in available $\mathrm{P}$ after vermicomposting was found, nor significant differences between treatments (Figure 1). A possible explanation is that in urban sewage sludge, $\mathrm{P}$ is expected as inorganic $\mathrm{P}$ from household detergents, which is not mineralized by microorganisms (Fassbender and Bornemisza 1994). To assess this assertion was beyond the scope of this study, but since $82 \%$ of all tropical soils in the Americas are phosphorus-deficient (Fassbender and Bornemisza 1994) fractionation was used to establish the chemical forms of P. Fractionation was carried out in sewage sludge and treatment $C$, the one with highest sewage sludge content (Figure 2). The highest share of $\mathrm{P}$ was found to be a slightly soluble fraction, which would indicate that $\mathrm{P}$ is immediately available to plants and/or easily lost through leaching or runoff (Penn and Sims 2002). However, as the $\mathrm{pH}$ of the vermicompost is acid, the second largest $\mathrm{P}$ fraction is bonded to $\mathrm{Al}$ in the insoluble fraction (Hedley et al. 1982); this diminishes the provision of $P$ to plants under field conditions (Adams 1995).

Available $\mathrm{K}$ was highest in composted cow dung (4238 $\mathrm{mg} \mathrm{kg}^{-1}$ ); treatments A (highest cow dung content) and $B$ were significantly different from $C$ (Figure 3). There is evidence that earthworms help increase

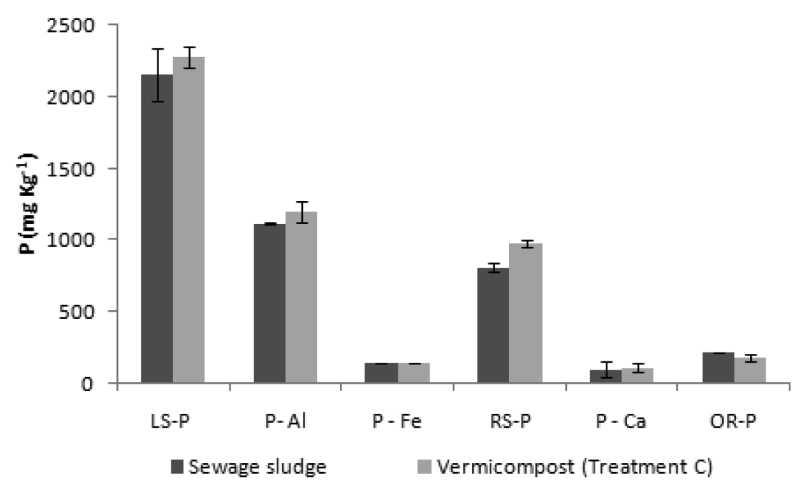

FIGURE 2. Fractionation of Phosphorus (LS-P: P slightly soluble; PAl: P bonded to Aluminum; P-Fe: P bonded to Iron; RS-P: reductant soluble P; P-Ca: P bonded to Calcium; OR-P: organic residual P) 


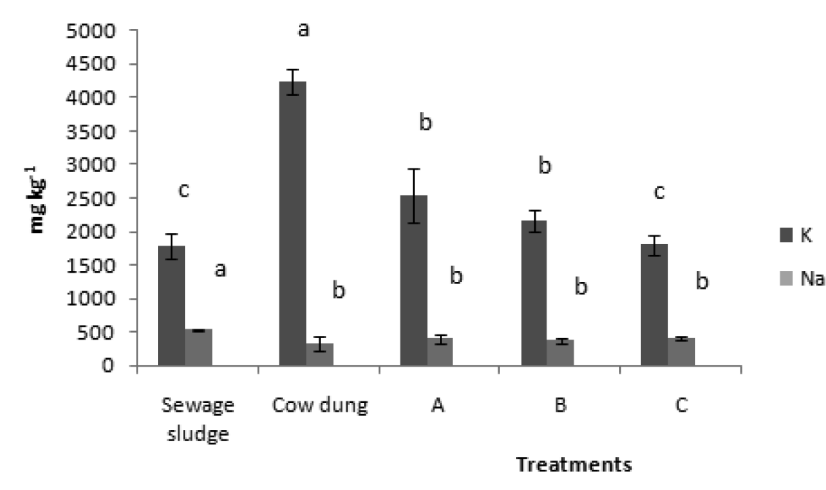

FIGURE 3. Available K and Na. Note: Bars indicate mean \pm standard error. Different letters in each bar indicate significant differences at $\mathrm{p}<0.05$.

the concentration of K (Garg et al. 2006; Suthar and Singh 2008) and promote the formation of potassiumhumic compounds, maintaining $\mathrm{K}$ available to plants (Rodríguez-Aragonés 1998).

As to available $\mathrm{Na}$ in the sewage sludge (528.76 $\left.\mathrm{mg} \mathrm{kg}^{-1}\right)$, it was not significantly different from treatment $C$ (Figure 3), but differed from treatments $A$ and $B$ (398.39 and $377.61 \mathrm{mg} \mathrm{kg}^{-1}$, respectively). Dayananda et al. (2008) suggest that sodium content can be a limiting factor in earthworm growth and reproduction, which could have been the case in this study. Also, high concentrations of this element inhibit plant growth and affect soil structure (Contreras-Ramos et al. 2005).

$\mathrm{C}: \mathrm{N}$ ratios, one of the most widely used indexes of organic waste maturity, were between 12.4 and 19.1 (Table 2). Similar values are reported elsewhere (Bansal and Kapoor 2000; Atiyeh et al. 2000). Vermicomposting is associated to fast rates of decomposition and mineralization of the organic matter and accelerates the decrease of the C:N ratio (Kaushik and Garg 2003). A decline of C:N to less than 20, indicates an advanced degree of maturity in organic waste (Senesi 1989). Whereas some studies suggest that $70 \%$ of sewage sludge in the vermicompost feed presented the best stability and maturity (ContrerasRamos et al. 2005), it was found here that up to $90 \%$ sewage sludge could be added, with good maturity.

All parameters in the treatments were in line with the vermicompost Mexican official guidelines (NMXFF-109-SCFI-2007, shown in Table 2). It must be mentioned that these results apply to the use of domestic wastewater sewage sludge, but caution is warranted when using industrial sewage sludge due to the presence of toxic chemicals (heavy metals and organic chemicals such as pharmaceuticals, hormone disruptors, flame retardants or pesticides), involving a potential risk for soil organisms and plants (Carbonell et al. 2009).
In addition to reducing processing times, this study shows that $E$. foetida can accept fresh sludge as feed, if combined with at least $10 \%$ cow dung. This appears to be true even when the earthworms drastically change environments from horse dung to fresh sewage sludge, notwithstanding suggestions to adapt earthworms to experimental conditions (Fründ et al. 2010; Kaushik and Garg 2003). The results found here buttress the idea that earthworms play an important role in the availability and nutrient cycling in natural and agricultural ecosystems (Jiménez et al. 2003; Brossard et al. 1996; Decaëns et al. 1999; Garg et al. 2006).

\section{Conclusions}

Treatments of 70:30 and 80:20 ratios of sewage sludge to composted cow dung were the most suitable for the reproduction of E. foetida, and to some extent, for their survival. Furthermore, the earthworms tolerated a 90:10 ratio, but this affected survival and reproduction: adult survival decreased to $79 \%$; juvenile and cocoon amounts were significantly lower suggesting substrate rejection by earthworms or toxicity around egg incubation time. This 90:10 treatment yielded the highest values of available $\mathrm{N}$ and $\mathrm{P}$, and a slightly lower concentration of available K. Earthworm activity in mixtures of sewage sludge and cow dung could significantly improve available nutrients such as $\mathrm{N}$ and agronomic physicochemical characteristics. There were significant differences in the parameters due to different ratios of sewage sludge added to the mixture, except in P. The vermicomposts obtained were within the range recommended by the Mexican guidelines for a good quality fertilizer.

Our recommendation for sewage sludge treatment is to divide the vermicomposting into two lots: one devoted to earthworm production (with 20-30\% cow dung content) and another one (with 10\% cow dung) devoted to maximize the production of soil amender or fertilizer and to reuse higher amounts of sewage sludge.

Finally, this study suggests that sewage sludge and cow dung vermicomposted with E. foetida can improve fertility and nutrient availability, as well as earthworm population growth, compared with the sewage sludge alone.

\section{Acknowledgements}

This research was supported by project CB-200601 from the National Science and Technology Council of Mexico (CONACyT). 


\section{References}

Adams, M., 1995. Fundamentos de Química de Suelos. Consejo de Desarrollo Científico y Humanístico. Venezuela, pp. 255-270.

Albanell, E., Plaixats, J. and Cabrera, T., 1988. Chemical change during vermicomposting (Eisenia foetida) of sheep cow dung mixed with cotton industrial waste. Biol. Fert. Soils, 6: 266-269.

Atiyeh, R.M., Domínguez, J., Subler, S. and Edwards, C.A., 2000. Changes in biochemical properties of cow dung during processing by earthworms (Eisenia Andrei Bouche) and the effects on seedling growth. Pedobiología, 44:709-724.

Bansal, S. and Kapoor, K.K., 2000. Vermicomposting of crop residues and cattle dung with Eisenia foetida. Biores. Technol., 73: 95-98.

Barois, I., Lavelle, P., Brossard, M., Tondoh, J., Martínez, M.A., Rossi, J.P., Senapati, B.K., Angeles, A., Fragoso, C., Jiménez, J.J., Decaëns, T., Lattaud, C., Kanyonyo, J.K., Blanchart, E., Chapuis, L., Brown, G.G. and Moreno, A.G. 1999. Ecology of earthworm species with large environmental tolerance and/or extended distributions. In Lavelle, P., Brussaard, L. Agroecosystems. CAB International, Wallingford, pp. 57-85.

Brossard M., Lavalle P. and Laurent J. 1996. Digestion of a vertisol by the endogenic earthworm (Polypheretina elongate) Megascoleuropean. J. of Soil Biol., 32: 107-111.

Capistrán, F., Aranda, E. and Romero, J. 2004. Manual de reciclaje, compostaje y lombricompostaje. $1^{\mathrm{a}}$ ed. $2^{\mathrm{a}}$ reimpresión. Instituto de Ecología A.C. Xalapa, Ver., México, pp. 90-99.

Carbonell, G., Gómez, P., Babín, M., Fernández, C., Alonso, E. and Tarazona, J.V., 2009. Sewage sludge applied to agricultural soil: Ecotoxicological effects on representative soil organism. Ecotoxicol. Environ Safe., 72: 1309-1319.

Cardoso-Vigueros, L. and Ramírez-Camperos, E., 2002. Vermicomposting of sewage: a new technology in Mexico. Water Sci. Technol., 46: 153-158.

Contreras-Ramos, S.M., Escamilla-Silva, E.M. and Dendooven, L., 2005. Vermicomposting of biosolids with cow dung and oat straw. Biol. Fertil. Soils., 41: 190-198.

Dayananda, D., Giraddi, R. and Gali, K. 2008. Effects of salt and sewage water on the survival and reproduction of three earthworms species used in vermicomposting. K. J. Agri. Sci., 21 (1): 52-54.

Decaëns, T., Rangel, A.F., Asakawa, N., Thomas ,R.J. and Lavelle, P. 1999. Carbon and nitrogen dynamics in ageing earthworm casts in grasslands of the Eastern plains of Colombia. Biol. Fertil. Soils, 30: 20-28.

Díaz, L.F., De Bertoldi M., Bidlingmaier, W. and Stentiford, E. 2007. Compost Science and Technology. Waste Management Series V.8. The Netherlands and U.K., pp. 167-176.

Epstein, E. 2003. Land application of sewage sludge and biosolids. Lewis Publisher. USA, pp. 119-121.

Esteller, M.V., Martínez-Valdés, H., Garrido, S., and Uribe, Q. 2009. Nitrate and phosphate leaching in a Phaeozem soil treated with biosolids, composted biosolids and inorganic fertilizers. Waste Manage., 29: 1936-1944.

Fassbender, H.W. and Bornemisza, E., 1994. Química de Suelos con énfasis en suelos de América Latina. Instituto Interamericano de Cooperación para la Agricultura. $2^{a}$ ed. $1^{a}$ reimp. Costa Rica, pp. 408-420.

Feller, C., Brown, G.G., Blanchart, E., Deleporte, P. and Chernyanskii, S.S. 2003. Charles Darwin, earthworms and the natural sciences: various lessons from past to future. Agric. Ecosist. Environ., 99: 29-49.

Franco-Hernández, O., Mckelligan-González, N., López-Olguin, A., Espinosa-Cerón, F., Escamilla-Silvia., E and Dendooven, L. 2003. Dynamics of carbon, nitrogen and phosphorus in soil amended with irradiated, pasteurized and limed biosolids. Biores. Technol., 87: 93-102.

Frederickson, J., Howell, G. and Hobson, A. M. 2007. Effect of pre-composting and vermicomposting on compost characteristics. Eur. J. Soil Biol., 43: S320-S326.

Fründ, H. C., Butt, K., Capowiez, Y., Eisenhauer, N., Emmerling, C., Ernst, G., Potthoff, M., Schädler, M. and Schrader, S. 2010. Using earthworms as model organisms in the laboratory: recommendations for experimental implementations. Pedobiologia., 53: 119-125.

Garg, P., Gupta, A. and Satya, S., 2006. Vermicomposting of different types of waste using Eisenia foetida: A comparative study. Biores. Technol., 97: 391-395.

Garrido, H. S., Martín del Campo, M. G. Esteller, M.V., Vaca, R. and Lugo, J. 2005a. Estudio de caso. Metales pesados en suelo tratado con lodo y composta (Toluca, México). In Moeller, Ch., Ramírez, G. A., Garrido, H. S., Díaz, D. C., (Eds). Tratamiento, disposición y aprovechamiento de lodos residuales SEMARNAT. México.

Garrido, S., Martín del Campo, G., Esteller, M.V., Vaca, R. and Lugo, G., 2005b. Heavy metal in soil treated with sewage sludge composting, their effects on yield and uptake of broad bean seeds (Vicia faba L.). Water, Air, Soil Pollut., 166: 303-319.

Guggenberger, G., Haumaier, L., Thomas, R.J., and Zech, W. 1996. Assessing the organic phosphorus status of an Oxisol under tropical pastures following native savanna using ${ }^{31}$ P NMR spectroscopy. Biol. Fertil. Soils, 23: 332-339.

Gutiérrez-Vázquez, E., Juárez-Caratachea, A., MondragónAncelmo, J. and Rojas-Sandoval A. 2007. Dinámica poblacional de la lombriz Eisenia foetida en estiércol composteado y fresco de bovino y ovino. Rev. Electr. Veter., Vol. VIII., Num. 7.

Hedley, M.J., Stewart, J.W.B. and Chauhan, B.S. 1982. Changes in inorganic soil phosphorus fractions induced by cultivation practices and by laboratory incubations. Soil Sci. Soc. Am. J., 46: 970-976.

Hernández- Herrera, J.M., Olivares-Sáenz, E., VillanuevaFierro, I., Rodríguez-Fuentes, H., Vázquez-Alvarado, R. and Pissani-Zúñiga, J.F. 2005. Aplicación de lodos residuales, estiércol bovino y fertilizante químico en el cultivo de sorgo forrajero (Sorgum vulgare Pers.). Rev. Int. Contam. Ambient., 21(1): 31-36.

Hogan, F., McHugh, M. and Morton, S., 2001. Phosphorus availability for beneficial use in sewage sludge products. Environ. Tech., 22: 1347-1353.

Jackson, L.M., 1982. Análisis químico de suelos. 4ª , ed. Omega. Barcelona, España.

Jiménez, J.J., Cepeda, A., Decaëns, T., Oberson, A. and Friesen D.K. 2003. Phosphorus fractions and dynamics in surface earthworm casts under native and improved grassland in a Colombian savanna Oxisol. Soil Biol. Biochem., 35, 715-727.

Kaushik, P. and Garg, V.K. 2003. Vermicomposting of mixed textile mill sludge and cow dung with epigeic earthworm Eisenia foetida. Biores. Technol., 90 (3):311-316.

Krishnamoorthy, R.V. 1990. Mineralization of phosphorus by faecal phosphatases of some earthworms of Indian tropics. Proc. Anim. Sci., 99(6): 509-518. 
Liu, X., Hu, Ch. and Zhang, Sh. 2005. Effects of earthworm activity on fertility and heavy metal bioavailability in sewage sludge. Environ. Inter., 31: 874-879.

Mariani, L., Jiménez, J.J., Asakawa, N., Thomas, R.J. and Decaëns T. 2007. What happens to earthworm casts in the soil? A field study of carbon and nitrogen dynamics in Neotropical savannahs. Soil, Biol. E Biochem., 39: 757-767.

Martínez, C.C., 1997. Potencial de la lombricultura. Ed. Texcoco. Texcoco, pp. 35-38.

Miralles del Imperial, R., Beltrán, E., Porcel, M., Beringola, L., Valero, J., Calvo, R. and Delgado, M. 2003. Disponibilidad de nutrientes por el aporte de tres tipos de lodo de estaciones depuradoras. Rev. Int. Contam. Ambient., 19: 125-134.

NMX-FF-109-SCFI-2007. Humus de lombriz (Lombricomposta) especificaciones y métodos de prueba. Secretaría de Agricultura, Ganadería, Desarrollo Rural, Pesca y Alimentación.

NOM-021-SEMARNAT-2000. Norma Oficial Mexicana que establece las especificaciones de fertilidad, salinidad y clasificación de suelos. Estudio, muestreo y análisis. Publicada en el Diario Oficial de la Federación.

Olsen, S.R. and Sommers, L.E. 1982. Phosphorus. In Page, A.L., Miller, R.H. and Keeney, D.R. (Eds). Methods of Soil Analysis, part 2. ASA, Madison, WI, pp. 404-430.

Penn, Ch. J. and Sims, T. 2002. Phosphorus forms in biosolidsamended soils and losses in runoff: effects of wastewater treatment process. J. Environ. Qual., 31: 1349-1361.

Porta, J., Lopez, A. M. and Roquero, C. 2003. Edafología para la agricultura y medio ambiente. Mundi Prensa. España, 251-271.

Primo, Y. E. and Carrasco D. J. 1981. Química Agrícola I.
Suelos y fertilizantes. Ed. Alhambra. España, 262- 265.

Rodríguez-Aragonés, C. 1998. Lombrices de tierra con valor comercial. Biología y técnicas de cultivo. La Habana, Cuba, pp. 48-50.

Rostagno, C.M. and Sosebee, R. E., 2001. Surface application of sewage sludge in the Chihuahuan desert: effects on soils physical properties. Arid Land Res. Manage., 15: 233-244.

Senesi, N., 1989. Composted materials as organic fertilizers. The Sci. Total Environ., 81/82: 521-524.

Shober A. and Sims, T. 2003. Phosphorus restrictions for land application of biosolids: current status and future trends. J. Envrion. Qual., 32: 1955-1964.

Short, J.C.P., Frederickson, J. and Morris, R.M. 1999. Evaluation of traditional windrow composting and vermicomposting for the stabilization of waste paper sludge (WPS). Pedobiologia, 43: 735-743.

Siddique, T.M. and Robinson, S., 2004. Differences in phosphorus retention and release in soils amended with animal cow dung and sewage sludge. Soil. Sci. Soc. Am. J., 68: 1421-1428.

Suthar, S., Singh, S., 2008. Vermicomposting of domestic waste by using two epigeic earthworms (Perionyx excavatus and Perionyx sansibaricus). Inter. J. of Environ. Sci. and Tech., 5(1): 99-106

Trigo, D., Barois, I., Garvin, M. H., Huerta, E., Irisson, S. and Lavelle, P. 1999. Mutualism between earthworms and soil microflora. Pedobiologia, 43: 866-873.

Vaca-Paulín, R., Esteller-Alberich M.V., Lugo-de la Fuente, J. and Zabaleta-Mancera H.A. 2006. Effect of sewage sludge or compost on the sorption and distribution of copper and cadmium in soil. Waste Manage., 26: 71-81. 